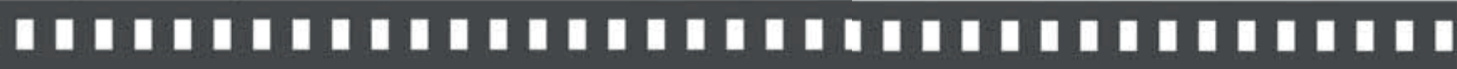

\author{
Telebasura y lenguaje coloquial. \\ La búsqueda de un comportamiento \\ ihumano?
}

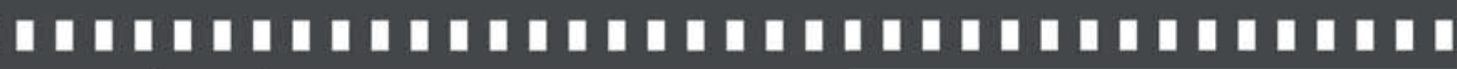

\author{
,Pilar Úcar \\ Álvaro Castro
}




\title{
Telebasura y lenguaje coloquial. La búsqueda de un comportamiento
}

ihumano?

\author{
Teletrash and colloquial language. The search for human \\ behavior?
}

Pilar Úcar*

Álvaro Castro***

Resumo: Dentro de la programación televisiva, destacan ciertos programas que son muy criticados por las escenas en las que se desarrollan, los personajes que aparecen y el contenido que muestran. Reciben el nombre de 'telebasura' y muestran 'realidades', que sirven de experimentos sociológicos y nos informan de los cotilleos de la farándula. De estos programas, surgen personajes que se convierten en modelos de conducta debido al gran poder de atracción del medio en el que se emiten. Sin embargo, ¿estos programas también pueden influir en nuestra forma de hablar y comunicar? Desde una perspectiva lingüistica y educativa, se va a evaluar cómo en un medio de comunicación en el que prima lo visual a lo comunicativo, existen ciertos programas que obligan a un lenguaje especifico por el contenido que muestran, y de qué manera pueden llegar a repercutir en el lenguaje coloquial de manera significativa. Con este trabajo nos disponemos a definir unos parámetros lingüísticos y comunicativos característicos de dicho género tan criticado. Pretendemos exponer la importante influencia de la telebasura en un registro idiomático familiar y determinar, cuál es la intencionalidad pragmática que lo anima. Por tanto, analizaremos el fenómeno de la telebasura desde una perspectiva lingüistica y comunicativa y su influencia en la población española.

* Doctora. Profesora del Departamento de Traducción, Interpretación y Comunicación Multilingüe, Universidad Pontificia Comillas (Madrid).

** Doctor. Profesor del Departamento de Relaciones Internacionales, Universidad Pontificia Comillas (Madrid). 
Palavras-chave: Telebasura. Lenguaje coloquial. Modelos de conducta. Lingüistica. Educación.

Abstract: Within the television programming, we highlight certain programs that are highly criticized for their scenes, their characters and content. They are called "teletrash" and display "realities" that serve as sociological experiments and inform us about show business gossip. From these programs, characters emerge becoming role models due to the great attractiveness of the media. However, can these programs also influence the way we talk and communicate? From the linguistic and educational point of view, this article seeks to evaluate how, in the means of communication, where the visual prevails, there are certain programs that force a specific language according to the content displayed, and how they can significantly affect colloquial language. With this work we set out to define the linguistic and communicative parameters characteristic of this so criticized genre. We intend to expose the significant influence of the teletrash on a familiar idiomatic record and to determine what is the pragmatic intention that stimulates it. Therefore, we will analyze the phenomenon of teletrash from a linguistic and communicative perspective and its influence on the Spanish population.

Keywords: Teletrash. Colloquial language. Behavior models. Linguistics. Education.

\section{Introducción}

La televisión forma parte de nuestro día a día. Nos sentamos en el sofá, la encendemos y nos disponemos a devorar con los ojos todo lo que nos ofrecen, desde los informativos con las noticias destacadas hasta los concursos de preguntas de cultura general. Pasamos tantas horas delante de la 'caja boba' que, queramos o no, influye en nuestro 
comportamiento y pensamiento. En un medio en el que la imagen supera en poder a la propia razón, resulta imprescindible analizar qué es lo que se emite y qué nos quieren mostrar.

Dentro de la programación televisiva, destacan ciertos programas que son muy criticados por las escenas en las que se desarrollan, los personajes que aparecen y el contenido que muestran. Reciben el nombre de 'telebasura'. En estos programas, se enseñan 'realidades', sirven de experimentos sociológicos y nos informan de los cotilleos de la farándula. Además, no sólo enseñan los detalles más sórdidos e íntimos de sus participantes, sino que fomentan nuestros instintos más viscerales e humanos. De estos programas, surgen personajes que se convierten en modelos de conducta debido al gran poder de atracción del medio en el que se emiten. Este contenido morboso y voyerista es un arma muy poderosa en las numerosas personas que lo siguen y resulta especialmente alarmante desde una perspectiva educativa.

Sin embargo, ¿estos programas también pueden influir en nuestra forma de hablar y comunicar? En un medio de comunicación en el que prima lo visual a lo comunicativo, a lo que se suman unos programas que obligan a un lenguaje específico por el contenido que muestran, ¿pueden llegar a repercutir en el lenguaje coloquial de manera significativa?

\section{La Telebasura. Definición}

El término 'telebasura' se escucha con mucha frecuencia por todos sitios. Asociamos unos géneros televisivos con unas características concretas (escándalo, morbo, etc.) a ese término. Sin 
embargo, ¿se sabe de qué se está hablando? ¿Qué es telebasura? ¿Cómo se podría definir?

La Real Academia Española define 'telebasura' como: "f. coloq. Conjunto de programas televisivos de contenidos zafios y vulgares" (TELEBASURA, 2016). Sin embargo, esta definición no logra hacer el ahondamiento necesario para un fenómeno televisivo de tal magnitud en España.

Muchosacadémicoshanaportadodefiniciones(FERNÁNDEZ BLANCO; CASTAÑO; BUENO; CUBELLS; ELÍAS PÉREZ, entre otros, citados por MARTÍNEZ FERNÁNDEZ et al., 2005, p. 441). No obstante, de todas las definiciones, la más aceptada es la aportada por la Agrupación de Telespectadores y Radioyentes (ATR, 1997), recogida en su Manifiesto contra la telebasura, que fue firmado por otros tantos organismos (CCOO, UGT, FIATYR, etc.). Según la Agrupación de Telespectadores y Radioyentes (ATR, 1997, p. 1), la 'telebasura' es una "forma de hacer televisión caracterizada por explotar el morbo, el sensacionalismo y escándalo como palancas de atracción de la audiencia", que se define por los "personajes que exhibe y coloca en primer plano, y, sobre todo, por el enfoque distorsionado al que recurre para tratar dichos asuntos y personajes". De este modo, la Agrupación de Telespectadores y Radioyentes - ATR (1997) aporta una serie de características que convierten la telebasura como factor de desinformación, aculturización y obstáculo para la opinión libre y fundamentada: el reduccionismo, la demagogia y el desprecio por derechos fundamentales, como el honor, la intimidad, el respeto, la presunción de inocencia, etc.

La Asociación de Usuarios de la Comunicación (AUC) publicó en 2004 una Aproximación a la Telebasura, también 
documento de referencia, en el que también se vierten otras ideas. La AUC califica a los programas de 'telebasura' cuando tratan de simular, o incluso de pervertir, los géneros periodísticos de referencia (debates, entrevistas, concursos...), dejando de lado su veracidad y centrándose en la espectacularidad (AUC, 2004, p. 2-3). Así, en este formato, primará la forma sobre el contenido, que estará plagado, según la AUC (2004), de mal gusto, de escándalo, agresión a la intimidad y denigración de los personajes que aparecen, exhibicionismo y provocación, sin ningún tipo de pudor y sin tener en cuenta los horarios de emisión para que los niños no los puedan ver. Por lo tanto, la AUC (2004, p. 4) define 'telebasura' como un:

[...] fenómeno televisivo que atenta contra la función social del medio; que menoscaba sus posibilidades expresivas y de contenido en términos tanto de información y formación como de entretenimiento, y que conculca valores constitucionales como el derecho a la veracidad, a la intimidad, a la dignidad de las personas y a la protección de la infancia.

Estas dos definiciones reflejan lo que supone el fenómeno de la 'telebasura'. Sin embargo, en este artículo, se considera 'telebasura' a aquellos programas que encajen dentro del decálogo que establece Gérard Imbert (2005), profesor de la Sorbona de París y de la Universidad Carlos III de Madrid, en su artículo 'Telebasura': de la telerrealidad a la teleficción, publicado en $E l$

País. El programa se considera 'telebasura' si cumple con alguna o con todas las características del decálogo. Imbert consigue en este decálogo no sólo incluir el contenido de este fenómeno, sino también las formas en la que se manifiesta, sus implicaciones éticas 
y su repercusión social. A continuación, se procede a resumir el decálogo de Imbert (2005):

1. La trivialización de los géneros periodísticos tradicionales (reportaje, debate, entrevista), que se integran en 'programas-contenedores' y concursos, con fines de entretenimiento y a veces de pretensiones sociológicas.

2. $\mathrm{Su}$ contenido se basada en los referentes fuertes de las '3S': sexo, sangre y sensacionalismo. Estas características extremas fomentan el voyerismo y el morbo.

3. Sus temas se acercan al ámbito de lo íntimo, de lo secreto, lo tabú, que lleva a una dilución entre lo que se considera público o privado. Es decir, se publicita lo privado, convirtiendo la intimidad en mero exhibicionismo, y también se privatiza lo público, ya que se usa la televisión como confesionario público.

4. Destaca la 'hipervisibilidad', como la denomina Imbert, que lleva a una hipertrofia del ver y la sobreexposición de los sujetos. El morbo provoca esa fascinación de lo invisible y de lo prohibido, que conduce a una mirada perversa y una exacerbación del ver.

5. Este fenómeno degrada la categoría de lo informativo. El uso de géneros periodísticos con fines espectaculares, la producción de una realidad paralela a la 'objetiva', y el cotilleo como referente informativo conducen a esta degradación.

6. Lo anteriormente mencionado lleva, por lo 
tanto, a la institucionalización de prácticas degradantes: el grito sustituye al debate, el enfrentamiento de personas sustituye a la dialéctica de ideas, el verbo y el gesto sustituye al rigor y al argumento, basados siempre en el maniqueísmo sin ninguna posible alterativa.

7. También Imbert afirma que esto se traduce en la aparición de nuevas formas narrativas, que se basan en la ficcionalización y la espectacularidad de lo cotidiano, que se hibridan (docurreality, por ejemplo) y confunden ciertas categorías (verdad/simulación), lo que puede llegar a ser peligroso para los menores.

8. Se potencia el 'habla profana', es decir, la del espectador anónimo frente a la opinión de un experto, lo que conlleva una falsa, e incluso manipulada, democratización del discurso.

9. La 'telebasura' tiene una tendencia al exceso, a lo barroco, a lo esperpéntico y la parodia, lo que produce una fragmentación del discurso, una dilución del sentido y se juega con las formas, predominando la imitación frente la creación.

10. La 'telebasura' crea un ambiente en el que toda jerarquía de valores desaparece. Las categorías morales (bien/mal) y estéticas (bello/feo) se difuminan y lo grotesco, lo monstruoso, lo freak es lo que se promociona, apoyando un héroe 'antihéroe', que derrocha desparpajo y desfachatez. Por lo tanto, lo negativo es el referente dominante en este fenómeno. 
Por lo tanto, la telebasura es un fenómeno en el que se priman las formas sobre el contenido, en el que lo importante es conseguir audiencia con el 'todo vale' frente a la calidad del producto televisivo.

\section{La Televisión Rosa Y La Telerrealidad Como Telebasura}

La telebasura abarca una gran cantidad de diversos tipos de programas, tales como las telenovelas o los dibujos animados violentos (PALACIO, 2007, p. 12). Sin embargo, se pueden diferenciar dos grandes géneros televisivos que encajan en nuestro concepto de telebasura:

\section{Televisión Rosa}

La televisión rosa es un término que usa Soto Vidal (2005) para denominar a aquellos programas de televisión que prestan atención a los contenidos propios de la llamada 'prensa del corazón', es decir, la que se centra en analizar la vida de los personajes conocidos y la farándula, que incluye un gran número de sectores (artistas, personajes de realities, clases sociales altas, etc.).

Con el surgimiento de este tipo de programas en televisión, se ha puesto de manifiesto la mercantilización de sentimientos que se está ejerciendo en la cultura televisiva actual basada en el contenido 'light', la banalidad y el beneficio rápido, sin ningún tipo de deber ni obligación moral. Se perciben además el surgimiento de nuevos personajes, que se convierten en productos de este negocio mediático, aparte de los tradicionales de las revistas del corazón, 
como es el caso de personajes relacionados con personajes famosos (exparejas, amigos, enemigos, etc.) o de los participantes de realities, que buscan sus minutos de fama vendiendo sus intimidades morbosas y sus líos amorosos, sin ningún tipo de escrúpulos ni reparo, y convirtiéndose en los nuevos ídolos mediáticos, como son los casos de Belén Esteban o de numerosos participantes de Gran Hermano, entre otros. Para ello, recurren a montajes, enfrentamientos y otro tipo de acciones, a costa de su honor, intimidad y la imagen de otras personas, para ganar una fama que le da una audiencia que conecta con ellos (SOTO VIDAL, 2005), la llamada 'sociabilidad mediática' que denomina Thompson (apud CÁCERES, 2007, p. 4) que toman como modelo su conducta para disfrutar de los mismos privilegios mediáticos de estos personajes supuestamente 'más afortunados' y anhelar esa polémica para buscar dinero fácil (SOTO VIDAL, 2005).

Este tipo de programas ha suscitado un gran interés en la actualidad por las audiencias. Massó (apud SOTO VIDAL, 2005, p. 53) afirmaba que su "éxito se entiende porque en la actualidad solo aceptamos mensajes ligeros, ya que lo sólido y serio aburre, de ahí que abandonemos los circunloquios propios de otro tipo de prensa y nos deleitemos sin contemplación con el género rosa, el más light del mercado periodístico."

\section{Telerrealidad}

La telerrealidad o reality show, como también se conoce, es un género televisivo que tiene como característica principal que, según Cáceres (2007, p. 4), "parten de la realidad, de la mano principalmente de sujetos anónimos, pero con un tratamiento basado 
en la espectacularización que los aleja de ella y los convierte en una construcción social y mediática no exenta de valores e ideología." Por lo tanto, se trata de un género televisivo que documenta situaciones en las que no se precisa guion ni plan fijado, en las que unos personajes desconocidos interactúan para ver lo que resulta. A partir de estos hechos, Cáceres (2007) afirma que surge una historia en los que se mezclan una serie de elementos (intimidad, hiperemotividad, dramatismo, violencia, sensacionalismo, entre otros) y que tiene como protagonista la gente común. Así, en los programas de telerrealidad, se cuentan historias personales dramáticas y de superación, se exponen conflictos y frustraciones y se muestran vidas diarias. Estas características, como en los programas de televisión rosa, suponen un acercamiento con la audiencia que se reconoce en esos personajes y que comparte sus mismos sentimientos y vivencias, lo que lleva a generar procesos de imitación y aprendizaje social, ya que estos personajes, que podrían ser nuestros vecinos o amigos, representan modelos de conducta.

Los programas de telerrealidad pueden ser de muchos tipos: concursos, programas de entrevistas, reportajes, programas de actualidad, docushows, talk shows, dating shows, talent shows... Casi todo lo que termine en "show" es telerrealidad (CÁCERES, 2007). Sea la forma que sea, la característica principal de la telerrealidad es la improvisación y las historias con emociones y reales (BLAS ARROYO, 2010). Además, como ocurre con la telebasura, la hibridación de géneros es muy frecuente, existiendo debates que no son debates (IMBERT apud CHALMETA CÁRDENAS, 2014), como es el caso de Gran Hermano. Incluso, la telerrealidad se combina entre sí para crear nuevos formatos. 
Como afirma el director de Mediaset España (apud PALOMO, 2014), "la telerrealidad es un ejemplo de mixtificación, ensambla con el coach, el dating, el talent [...] Operación triunfo fue un paradigma de ello, pero hay muchos otros ejemplos: Supervivientes combina la convivencia con la supervivencia; Pekín Express lo hace con la aventura, Mira quién salta es un concurso combinado con convivencia [...]."

Este género comienza en los años 90 en la televisión holandesa, con la serie Nummer 28, un programa que juntaba desconocidos y grababa sus interacciones. A finales de los 90 , ya surgía en EEUU los grandes realities Survivor y Big Brother, basados ya en competiciones. La telerrealidad comenzó su boom fuerte en España con el estreno del primer gran reality show de nuestro país: Gran Hermano (GH). En el año 2000, GH supuso un antes y un después en la cultura televisiva de nuestro país. Para entender este punto de inflexión, es preciso señalar que más de 9 millones de espectadores vieron la final de esta primera edición, con un $70,8 \%$ de cuota de share. El segundo gran hito de la telerrealidad en España fue Operación Triunfo (OT), que fue seguida por unos 13 millones de televidentes (PALOMO, 2014).

Por lo tanto, para concluir, podemos observar que la televisión rosa y la telerrealidad son dos géneros televisivos que encajan en las características del decálogo de Imbert (2015) $\mathrm{y}$ se pueden considerar, por lo tanto, telebasura. Son géneros especialmente ligados con mostrar hechos reales y vender las emociones de personas, sean de la calle como famosas. Ambos géneros son fácilmente combinables, ya que, como ya se ha afirmado, la telerrealidad puede generar personajes que son usados 
por la televisión rosa y, además, existen programas de telerrealidad en los que participan personajes de la televisión rosa, como son los casos de Supervivientes, GH VIP, Mira quién baila y tantos otros. Incluso, se crean los realities rosas, un género híbrido de ambos, como podría considerarse Sálvame Diario (SÁNCHEZESCRIBANO, 2012, p. 8). Sin embargo, es importante resaltar la capacidad de imitación y de aprendizaje social que generan estos dos géneros, que logran conectar con la audiencia, estableciendo una 'sociabilidad mediática' (THOMPSON apud CÁCERES, 2007, p. 4) con los personajes mediáticos que dichos programas generan (BLAS ARROYO, 2010, p. 186), que son posibles modelos de conducta para los espectadores. Como afirma Pérez Rodríguez (2005, p. 200), "con algunos nos identificamos tanto que los idolatramos y convertimos en modelos que imitamos, a veces de forma inconsciente."

\section{La televisión. Comportamiento y lenguaje}

Los comienzos de la televisión llevaron al medio a ser voz de lo público, a ser el 'perro guardián' de los asuntos de interés público. En la actualidad, se ha producido una escisión entre esta concepción y la intimidad con finales comerciales (CÁCERES, 2007). Esto ha derivado a que prime lo emotivo frente a lo racional, es decir, la imagen con respecto al lenguaje (SÁNCHEZ-ESCRIBANO, 2012). La imagen está mucho más conectada a una emoción que el lenguaje, que es un elemento mucho más abstracto. La imagen satisface por el mero hecho de verla, mientras que el lenguaje conlleva que la audiencia reflexione (SÁNCHEZ-ESCRIBANO, 
2012, p. 7). La imagen designa la realidad, la muestra sin trabas (PÉREZ RODRÍGUEZ, 2005, p. 198). Por ello, la televisión permite consumir imágenes sin necesidad de un elemento de abstracción y racionalidad. La televisión desata emociones sin necesidad de entender las cosas que nos rodea, provoca un efecto de realidad porque la imagen responde afirmativamente a la existencia de algo. Así, la televisión ha llevado a crear una nueva fórmula, la de "ver es comprender" (SÁNCHEZ-ESCRIBANO, 2012, p. 8)

Aprovechando esta fórmula, la televisión, con las directrices de los grandes grupos mediáticos (SÁNCHEZ-ESCRIBANO, 2012, p. 4), ha comenzado a sobrepasar, como ya se ha mencionado, los límites de lo meramente informativo para trasmitir una realidad espectacularizada que obliga a un diseño previo por la cadena (IMBERT apud CHALMETA CÁRDENAS, 2014, p. 6). Elegir este medio, vistas las implicaciones anteriores, conlleva una deliberada construcción de una realidad para ser consumida (SÁNCHEZESCRIBANO, 2012, p. 7).

La búsqueda de esa realidad espectacularizada obliga a difuminar las barreras entre qué es real y qué es ficticio (CÁCERES, 2007 , p. 12). Se puede afirmar que lo que ofrecen los programas de televisión rosa y telerrealidad es real porque los personajes y las historias que aparecen son reales, pero no se puede olvidar que lo que aparece en la pantalla no es la realidad y que lo que aparece no es toda la realidad (CÁCERES, 2007, p. 13). Esta realidad que se nos presenta sufre un proceso de mediación, que consiste en la selección y tratamiento de una trama, ajustados a un tiempo y un espacio mediáticos, para crear una realidad argumental, una trama que debe interesar a la audiencia (CHALMETA CÁRDENAS, 
2014, p. 4). Se hace un tratamiento ficticio de la realidad. En otras palabras, parafraseando a Cáceres (2007, p. 13), estos programas no muestran la realidad como sucede, sino que es una realidad recreada en un plató, tratada con los intereses de la cadena y unas exigencias comunicativas. Ya no se cuenta una historia, sino se crea una según los intereses de los grupos mediáticos y según se precise para captar audiencia (SÁNCHEZ-ESCRIBANO, 2012, p. 4).

El peligro de lo anterior es que, si la imagen se 'engulle' como tal, con un discurso más emocional que racional, creyendo que "ver es comprender", la audiencia al final toma como referencia una realidad manipulada por los intereses de los grupos mediáticos (SÁNCHEZ-ESCRIBANO, 2012, p. 19). Esa imagen, por muy ligera que sea, no es un reflejo de la realidad, sino una reproducción elaborada (PÉREZ RODRÍGUEZ, 2005, p. 200). Es decir, los espectadores observan una realidad creada especialmente para el espectáculo y, además, la extrapolan como suya, al identificarse con los personajes reales (SÁNCHEZ-ESCRIBANO, 2012, p. 8).

Consiguen que esa 'hiperrealidad', caracterizada por la inmediatez y la hipervisibilidad, como mecanismo de construcción de la realidad convierta esa representación verosímil en una representación real, desfigurando la ficción de la realidad (CÁCERES, 2007, p. 18). Ya no es sólo imitar como ocurre en las parodias, sino se trata de suplantar lo real por lo ficticio (SÁNCHEZESCRIBANO, 2012, p. 9).

Todo esto está además programado para una audiencia acostumbrada al mundo audiovisual, que necesita entretenerse para olvidar un duro día a día, que no quiere esforzarse para ver televisión, que está harta de la política (CHALMETA CÁRDENAS, 
2014, p. 3). Las emociones de los participantes de estos programas seducen a una audiencia que no separa la persona (privada) del personaje (público) (CHALMETA CÁRDENAS, 2014, p. 6). La identificación con esta realidad lleva a que esta 'realidad ficticia' se enrede con nuestro espacio real y la audiencia va perdiendo esa capacidad de diferir entre lo imaginario y lo verdadero (CÁCERES, 2007, p. 13). Se produce así una deconstrucción de la sociedad, que acoge a estos personajes desprovistos de valores morales e intelectuales como su realidad social (CHALMETA CÁRDENAS, 2014, p. 4). La televisión se vale de versiones extremas de personajes para desvirtuar la realidad y legitimar la creada (BLAS ARROYO, 2010, p. 185). Este es el caso de Belén Esteban, ex pareja del torero Jesulín de Ubrique, que se convirtió en la "princesa del pueblo". Según Sánchez-Escribano (2012) en La 'belenestebanización' de la sociedad, su poder de seducción a la audiencia, que se identifica con ella, se debe a su historia, que ha derivado en una "telenovela" construida en colaboración con Telecinco. Se trata de un "telenovela" con una idea maniquea (la heroína del pueblo frente los villanos de Ubrique) y una evolución abierta que da la impresión de que su vida siempre tiene algo nuevo que se solucionará en el programa siguiente (SÁNCHEZ-ESCRIBANO, 2012 , p. 12, 13). Esto ha servido no sólo para ganar beneficios sino además para convertirse en representante política y voz del pueblo, que muestra una versión unívoca e individualizada de la realidad, sin distintos pareceres, produciendo un falso consenso y una fuerte homogeneización que lleva a la audiencia a tomar a Belén Esteban como referente (SÁNCHEZ-ESCRIBANO, 2012, p. 15-16). Así, se imponen no sólo sus ideas, sino también las de Telecinco, que es 
quien construye su realidad, lo que lleva a que la cadena preserve su poder mediático (SÁNCHEZ-ESCRIBANO, 2012, p. 16). No se debe olvidar que todo esto es parte de un espectáculo, que gira en torno a sus escándalos e intimidades, lo que lleva a que se preste y se dé menos relevancia a los asuntos verdaderamente importantes para la sociedad (SÁNCHEZ-ESCRIBANO, 2012, p. 17).

De este modo, hemos comprobado cómo el poder mediático, a través de la televisión, no sólo crea su propia realidad con personas reales e historias ficticias, sino que además logra influir y transformar la concepción que la sociedad tiene de sí, con espectadores que creen que "ver es comprender" y adoptan la realidad mediática que se les ofrece.

\section{El Lenguaje del Discurso Televisivo}

La telebasura se emite por un medio de comunicación de masas que posee un lenguaje concreto y característico del medio, con el que nos trasmite un mensaje. Este lenguaje resulta de especial relevancia debido a, como ya se ha mencionado, la gran repercusión que este medio tiene en la sociedad y a la tendencia del medio no sólo a dirigir las informaciones sobre el panorama actual, sino también las percepciones de nuestro mundo (CÁCERES, 2007, p. 2).

El discurso televisivo se basa en la yuxtaposición de tres elementos para trasmitir su contenido: lo sonoro, lo icónico y lo lingüístico. Por lo tanto, se comprueba que el lenguaje de la televisión es un lenguaje híbrido con elementos verbales y no verbales, característicos del mensaje audiovisual (PÉREZ RODRÍGUEZ, 2005, p. 200). Además, se puede afirmar, como ya 
se ha comprobado, que el poder de lo icónico supera al lingüístico, completando o modificando la interpretación del discurso verbal (SÁNCHEZ-ESCRIBANO, 2012, p. 6).

Gracias a estos elementos, en este discurso predominan las funciones fática (canal), emotiva (emisor) y conativa (receptor) del lenguaje, según la división de Jakobson. Las funciones emotiva y conativa hacen referencia a la trasmisión del contenido, en la que el emisor, es decir, quienes realizan el programa emitido, tratan de interpelar al receptor. Por lo tanto, se comprueba aquí que el discurso televisivo se centra en la creación de un producto del interés del receptor, que se ve combinado por la función fática, que articula y explicita las funciones del emisor y el receptor. Todo esto se desenvuelve en un contexto comunicativo concreto, que, como se ha analizado, tiende a ser un contexto espectacular (CARMONA, 2010).

Aunque lo icónico supere a lo lingüístico en este lenguaje, lo lingüístico es lo que nos interesa en esta investigación: un lenguaje oral, con una improvisación 'guionizada', que prefiere el directo y lo inmediato, con una jerga especializada y un conjunto entremezclado de tipos de discurso, tanto expositivo, como argumentativo y narrativo (PÉREZ RODRÍGUEZ, 2005, p. 200). En este sentido, se ha de entender que el lenguaje verbal de la televisión deriva del de los medios de comunicación escritos que aportaron la intención inicial del medio televisivo: informar. Por lo tanto, las pautas textuales que marcan la prensa escrita son las que, en cierta medida, marcan las premisas del lenguaje oral de la televisión (MARÍN apud FRUTOS, 2003), que son las siguientes: 
1. Claridad, brevedad y concisión del mensaje para impactar y no aburrir

2. El mensaje lingüístico debe acompañar al mensaje icónico

3. La estructura de las frases debe ser sencilla, ordenándolas con la fórmula sujeto + verbo + predicado.

Con esto en mente, Frutos (2003) toma la idea de Marín y establece tres ámbitos en los que es necesario prestar atención:

1. Pronunciación: El tono, el timbre, la duración y la intensidad del mensaje determinan su impacto e intención. Esto lleva a la expresividad de la palabra y la necesidad de que, usando los actos de habla de Austin, el acto locutivo debe tener relación con el acto ilocutivo y sus efectos perlocutivos. También se han de tener en cuenta la puntuación de las frases orales para mantener un ritmo, el estilo telegráfico que debe acompañar a las imágenes, la pronunciación de extranjerismos, que normalmente se castellanizan, entre otros.

2. Sintaxis: Para cautivar al espectador, es imprescindible el diseño correcto del texto orado. Se ha de recordar que el texto televisivo se prepara para hablarse. De este modo, el orden de las palabras para lograr que el espectador se interese por lo que el emisor quiere transmitir, los hipérbatos para llamar la atención, el juego entre estilo directo e estilo indirecto y las elipsis contribuyen al estilo televisivo. Se deben además evitar las frases en pasiva, las 
perífrasis, la impersonalidad, entre otros porque desvían la atención del espectador y merman el mensaje de lo icónico.

3. Semántica: Es de vital relevancia porque el uso de las palabras por los medios afecta al uso que se le dé en el lenguaje habitual, debido a su repercusión. Así, los cambios e innovaciones semánticas, el uso de siglas o tecnicismos para captar el significado de la imagen, el uso de cultismos en contextos entendibles por el espectador, de proverbios y eufemismos, así como de figuras retóricas como la personificación, son recursos que Marín observa en el lenguaje televisivo.

\section{La Descortesía Mediático-Lúdica}

Los programas de telebasura recurren con frecuencia a eventos comunicativos en los que predomina el ataque, el desacuerdo, el enfrentamiento y la agresión verbales.

La descortesía supone "la violación del contrato conversacional basado en los derechos y obligaciones que los interlocutores se conceden mutuamente" (SOPEÑA BALORDI; OLIVARES PARDO, 2000, p. 1029). Por lo tanto, si la descortesía es lo opuesto a la cortesía, se podría definir como el "intento de destruir la imagen social del otro, en pos del beneficio del hablante" (FUENTES RODRÍGUEZ; ALCAIDE LARA, 2008b, p. 16). La descortesía se relaciona también con la agresividad y la violencia, que surgen de las estrategias para la función del discurso descortés, que busca dañar la imagen del otro. En lo verbal, esto se relacionaría con actos ilocutivos intimidatorios como defensa o mantener una postura (actos agresivos) y la ejecución de actos ilocutivos con 
intención de dañar a otro mediante el insulto, la ridiculización, etc. (actos violentos) (p. 17-18).

La descortesía verbal se usa en el discurso televisivo de estos programas como medio realmente eficaz de captar audiencia (FUENTES RODRÍGUEZ; ALCAIDE LARA, 2008a, p. 22). La violación de lo cortés, de lo que está socialmente aceptado y de lo que resulta adecuado atrae. El placer de lo prohibido y la satisfacción voyeurística de completar las intimidades y el sufrimiento humano lleva a que, en estos programas, la violencia se manifieste (BLAS ARROYO, 2010, p. 202) y que, además, productores y directores animen a ello (BRENES, 2010, p. 710). Brenes (2010, p. 709) denomina 'descortesía mediáticolúdica' a esta "utilización consciente y estratégica en los medios de comunicación de masas de elementos verbales descorteses o violentos, en aras de una finalidad muy determinada: divertir al telespectador para conseguir, así, aumentar el consumo de un determinado producto.” Brenes (2010, p. 710) además afirma que esta descortesía mediático-lúdica ha sido la causante de que el medio televisivo haya sufrido esta degeneración de lo informativo a lo lúdico, transformando los elementos que definían al medio, ya que los programas se han centrado sólo para lograr esto. De este modo, el éxito de estos programas se basa en el uso de dicha descortesía mediático-lúdica. En el caso de la televisión rosa, los temas con los que empezaron, es decir bodas, fiestas, etc., pasaron a divorcios, infidelidades y problemas con la justicia (BRENES, 2010, p. 711), convirtiéndose en 'pseudotertulia' más que en tertulia (BRENES apud ORTIZ VISO; FERNÁNDEZ GARCÍA, 2014, p. 290). En el caso de la telerrealidad, centrar las interacciones en la agresividad 
y violencia verbales, buscándolo en todo momento y desviándolo de la intención principal del programa (BLAS ARROYO, 2014, p. 40), como ocurren cuando realizan resúmenes de Gran Hermano, que resaltan momentos en los que se producen actos lingüísticos descorteses.

De hecho, se llega a demostrar (BLAS ARROYO, 2010; BRENES, 2010), que la información que se trasmite ya no interesa tanto, incomprensible por la descortesía mediático-lúdica, sino el enfrentamiento radicalizado entre los participantes, llegando incluso a desvirtuar la intención principal que tuviese el programa. Si tenemos en cuenta que la descortesía verbal ya forma parte del discurso de estos programas, que se usa como espectáculo para atraer audiencia y que además se consigue con éxito, se puede afirmar que esta descortesía no afecta negativamente a quien la usa, sino que, en cambio, favorece y reafirma su posición en la interacción, por lo que le beneficia (BRENES, 2007, p. 16).

\section{Oralidad y coloquialización en televisión}

La tendencia a la espectacularización y la primacía de lo íntimo y lo personal en estos programas lleva a una coloquialización de los mensajes que transmiten. Como afirma Briz (2013), la inmediatez que exige estos programas lleva a una relajación lingüística y social y, por ende, afecta en el uso de la deixis, en la aparición de rasgos sociolectales, en el léxico usado y, también, en la atenuación del lenguaje, al existir también una mayor cercanía física entre los participantes.

Esta coloquialidad se ha realizado de forma estratégica, no sólo porque las condiciones del formato lo exigen (como es 
el caso de los programas analizados), sino porque los requisitos para una televisión centrada en el espectáculo y en la explotación comercial de los sentimientos e intimidades humanas obligan a ello (LÓPEZ SERENA, 2014, p. 67). La audiencia demanda eso y, por lo tanto, demanda un registro adecuado a ello. Por lo tanto, en estos programas, como afirma Briz (2013), la coloquialidad provoca turnos de palabras más libres, más dinámicos y más dialógicos, es decir, un mayor grado de oralidad.

También se ha de afirmar que, en muchos casos, el formato origen no exige esa coloquialidad, sino que es impuesta con el fin de atraer audiencias, como es el caso de la cercanía intimista del programa Salvados, que lleva a una entrevista, en principio una interacción comunicativa formal a tener un tratamiento de conversación informal, en el que el entrevistador trasmite una imagen alineada con lo que espera la audiencia, ejerciendo de su portavoz y, a la vez, mejora su imagen frente a la misma (FUENTES RODRÍGUEZ, 2014, p. 106).

Este dinamismo y oralidad implica también la aparición de la descortesía como mecanismos para atraer a la audiencia, ya que las manifestaciones constantes de descortesía caracterizan al lenguaje informal y coloquial (LÓPEZ SERENA, 2014, p. 66). Además, esta oralidad sirve para dar credibilidad a los personajes ficticios de estos programas, ayudando a la construcción de la realidad anteriormente descrita (LÓPEZ SERENA, 2014, p. 67).

Por lo tanto, el lenguaje del discurso televisivo da más importante a la imagen que al lenguaje verbal, que debe ser demás breve, conciso y capaz de atraer la atención. Sin embargo, con la deformación de las intenciones por el uso de la descortesía 
mediático-lúdica y otros elementos característicos de la telebasura, conlleva también la deformación del lenguaje verbal televisivo anteriormente expuesto. Además, Briz (2013) confirma que la coloquialización del lenguaje como estrategia comunicativa es una manipulación que ayuda al éxito y a la veracidad de estos programas. Por lo tanto, se puede afirmar que el lenguaje televisivo se deforma debido a las características de la telebasura.

\section{¿Cómo Es El Lenguaje De La Telebasura?}

Una vez analizados los términos anteriores, se pueden establecer una serie de parámetros comunicativos y lingüísticos que se deducen de los mismos.

Por lo tanto, el lenguaje de la telebasura se caracteriza por:

- Una primacía del significante sobre el significado, es decir, al ser un fenómeno en el que los contenidos se degradan y se priman las formas, lo esencial en el lenguaje de estos programas es el 'cómo se dice' que el 'qué se dice', ya que el mensaje carece de interés. Si utilizamos la teoría de los actos de habla de Austin, prima el acto locutivo sobre el acto ilocutivo.

Se prefieren oraciones breves y sencillas, debido a las características del medio por el que se emite y por la deformación de contenidos.

Al redundar las formas y perder el sentido del mensaje, se percibe una exageración del lenguaje, que llega a ser grotesco y disparatado. 
- Impera un registro que hacen pasar por 'coloquial' y 'natural' debido a la construcción de la realidad generada por el medio. Es decir, el lenguaje de la telebasura se considera como 'el de la gente de la calle' porque la gente de la calle cree que esa es la realidad que viven. Esto se confirma con los altos niveles de audiencia registrados.

Como se busca la cantidad (de dinero, de audiencia conseguidas) en vez de la calidad, esta coloquialidad se caracteriza por un lenguaje no cuidado e incorrecto.

- La agresividad y la descortesía verbales no resultan intrínsecas a la telebasura. Estas sólo surgen en los programas de telebasura con personajes populares, mediáticos y polémicos, que recurren a esta estrategia para captar seguidores, que es el efecto perlocutivo de acto ilocutivo de chillar, agredir o amenazar, entre otros. Sin embargo, sí que se puede afirmar que la telebasura tiende a ensalzar lo negativo, como afirmaba Imbert (2005), por lo que el lenguaje de la telebasura suele caracterizarse por un alto grado de descortesía mediático-lúdica (BRENES, 2010).

\section{¿Existe una Influencia en El Lenguaje Coloquial en España?}

Para comprobar el impacto que ha tenido la telebasura en España, se realizó una encuesta que nos permite ver la relación que existe entre estos programas y su impacto en el lenguaje coloquial de los españoles. A continuación, se resumirán las conclusiones extraídas de las respuestas obtenidas. 
Las preguntas giraban en torno a los programas de telebasuras vistos por la audiencia, mencionando entre otros Sálvame, Gandía Shore y Mujeres, Hombres y Viceversa; las expresiones surgidas de los mismos, como “¡Yo por mi hija MA-TO!” de Belén Esteban y el "Tiki Tiki" o el "Hasta nunqui" de la concursante de realities Ylenia Padilla; y las situaciones en las que se usaban y escuchaban. La encuesta fue difundida por redes sociales en noviembre de 2016.

Tras analizar las 509 respuestas recibidas de personas de entre 14 y 59 años, la población encuestada concibe la telebasura como un fenómeno negativo a todos los niveles, calificándola como 'mierda' o 'vergüenza' y considerándola como un fenómeno que no aporta nada a la sociedad. Es un fenómeno muy seguido, ya que 9 de cada 10 encuestados han visto programas de telebasura, aunque fuesen pocas veces, y la influencia lingüística afecta más a mujeres y jóvenes estudiantes de entre 14 y 24 años. Los encuestados definieron el lenguaje de la telebasura como ordinario, irrespetuoso y agresivo, concordando con la agresividad y descortesía verbales expuestas en este artículo. También se percibe una tendencia al lenguaje morboso, vulgar y descuidado. Además, al redundar las formas y perder el sentido del mensaje, los encuestados perciben una exageración del lenguaje.

Un 78,78\% de los encuestados han afirmado que sí se ha copiado el lenguaje de la telebasura en el lenguaje coloquial y un $\mathbf{9 0 , 3 7 \%}$ han afirmado que sus conocidos han adoptado algunas de las expresiones propuestas que surgieron de la telebasura, siendo el "Holi" de Ylenia Padilla la expresión con mayor número de frecuencias.

La influencia más importante a nivel lingüístico es la 
imitación, adopción y repetición de expresiones, frases $y$ muletillas famosas que han surgido de estos programas, sobre todo entre la población estudiante universitaria. Al ser un fenómeno en el que se prima el "cómo se dice" que el "qué se dice", se entiende que, a la hora de usar estas expresiones, no se tiene en cuenta el significado de las mismas. Los encuestados alertan que, aunque se empiecen a imitar por mera broma o para reírse, poco a poco se han ido incorporando en sus expresiones cotidianas. En cuanto a las situaciones en las que se dicen, aparecen en situaciones con amigos y personas de confianza, en un ambiente informal y en momentos de risa o broma.

Se ha demostrado que los programas tienen la capacidad de incorporar expresiones y coloquialismos nuevos en el lenguaje, ya que, a la hora de preguntar sobre expresiones que recordaban de programas de telebasura, las que consiguieron mayores frecuencias fueron aquellas que tienen un vocabulario inventado, como la palabra 'edredoning' de Gran Hermano.

Vistos los resultados, se puede afirmar que la capacidad de influencia no se determina por el número de horas dedicadas a ver programas de estas características, sino que, cuanto más mediático, controvertido y popular sea el o los personajes que participen en los programas de telebasura, más capacidad posee de influir en el lenguaje de los encuestados. Además, cuanto más violento y agresivo es el lenguaje utilizado, más se usa por los encuestados, y cuanto más "graciosas" y amenazantes son las expresiones, más se escuchan por los encuestados. Por último, los encuestados alarman de que muchos de sus conocidos no sólo imitan sus frases, sino la forma de hablar y comportarse de esos modelos polémicos, 
degradando no sólo el lenguaje de los mismos, sino también la comunicación entre ellos.

\section{Conclusión}

Por lo tanto, la telebasura constituye un fenómeno televisivo sensacionalista, en el que priman las formas de trasmitir la información frente al contenido de los datos y opiniones aportadas para lograr entretener al espectador, que, a su vez, demanda mensajes breves y sencillos, en los que impera un registro coloquial y un alto grado de descortesía y agresividad verbales, que deforman y transforman la intención original del programa, y genera personajes de gran influencia. Como la televisión es un medio de tan alta repercusión social, con una tendencia a la cantidad (mayores beneficios, audiencias, etc.) que, a la calidad, lo que se logra con estos programas, justifica la importancia de analizar el impacto que tienen estos programas en el lenguaje coloquial de los españoles.

No podemos negar que la televisión es un medio transmisor y transgresor, y como tal, refleja el sentir de una realidad en todo momento cambiante. Las teleseries, los programas de "realidad" suponen un espejo en el que la población se ve proyectada y se reconoce. A través de la pantalla y su magia, la realidad es compartida por miles de espectadores; por lo tanto, cumple una función de aproximación, cercanía a la vida cotidiana. Quizá estos programas resulten terapéuticos o, en algún caso, bálsamo apaciguador de las convulsiones que se viven a diario. Convendría dejar espacio a la evasión sin obsesión al juego caleidoscópico de la magia que observamos en la pantalla. 


\section{Referências}

AGRUPACIÓN DE TELESPECTADORES Y RADIOYENTES - ATR. Manifiesto contra la telebasura. Madrid: ATR, 1997. Disponible en: http://www.hazteoir.org/sites/default/files/upload/ MANIFIESTO\%20CONTRA\%20LA\%20TELEBASURA.pdf. Acceso en: 10 abr. 2019.

\section{ASOCIACIÓN DE USUARIOS DE LA COMUNICACIÓN} - AUC. Aproximación a la Telebasura. 2004.

Disponible en: http://www.auc.es/Paginas/download. php?type $=$ doc \&year $=2004 \&$ file $=$ docu15.pdf. Acceso en: $10 \mathrm{abr}$. 2019.

BLAS ARROYO, José Luis. Factores condicionantes en la producción y recepción de la descortesía en un. Revista de Filología, Laguna, v. 32, p. 17-44, 2014. Disponible en: http:// publica.webs.ull.es/upload/REV\%20FILOLOGIA/322014/ Revista\%20de\%20Filolog\%C3\%ADa\%2032.pdf. Acceso en: 10 abr. 2019.

BLAS ARROYO, José Luis. La descortesía en contextos de telerrealidad mediática. Análisis de un corpus español. In: ORLETTI, F.; MARIOTTINI, L. (Des)cortesía en español. Espacios teóricos y metodológicos para su estúdio. Roma: Universidad Roma Ter: Programa EDICE, 2010. p. 183-207.

BRENES, Ester. Estrategias descorteses y agresivas en la figura del tertuliano televisivo: ¿trasgresión o norma? Lingüística en la red. Linred.com, [S.l], p. 1-19, jul. 2007. Disponible en: http:// www.linred.es/articulos_pdf/LR_articulo_22062007.pdf. Acceso en: 10 abr. 2019.

BRENES, Ester. Violencia verbal y discurso televisivo. Análisis pragmalingüístico de la figura del moderador-excitador. Discurso y Sociedad, Barcelona, v. 4, n. 4, p. 706-730, 2010. Disponible en: 
http://www.dissoc.org/ediciones/v04n04/DS4\%284\%29Brenes. pdf. Acceso en: 10 abr. 2019.

BRIZ, Antonio. Variación pragmática y coloquialización estratégica. El caso de algunos géneros televisivos (la tertulia). En: FUENTES RODRÍGUEZ, Catalina. (Des)cortesía para el espectáculo: estudios Madrid: Arcos/Libros. 2013. p. 89-125. CÁCERES, Maria Dolores. Telerrealidad y aprendizaje social. Icono 14. Revista de Comunicación y Nuevas Tecnologías, Madrid, v. 5, n. 9, p. 1-21, junio, 2007. Disponible en: http://www. icono14.netojs/index.php/icono14/article/view/375/251. Acceso en: 10 abr. 2019.

CARMONA, Juan Francisco Torregrosa. El discurso televisivo actual. Características y tendencias. Sphera Publica, Guadalupe, n. 10, p. 195-206, 2010. Disponible en: http://www.redalyc.org/ articulo.oa? id=29719345013. Acceso en: 10 abr. 2019.

CHALMETA CÁRDENAS, Jorge. El transformismo televisivo. Aularia, Andalucía, n. I, p. 3-10, 2014.

FRUTOS, Juan Tomás. El lenguaje en televisión, una unión de intereses y de fines. Campus Digital, Murcia, 2003. Disponible en: https://www.um.es/campusdigital/Cultural/lenguaje\%20TVE.htm. Acceso en: 10 abr. 2019.

FUENTES RODRÍGUEZ, Catalina, ALCAIDE LARA, Esperanza (2008). La descortesía en los medios. En: FUENTES RODRÍGUEZ, Catalina, ALCAIDE LARA, Esperanza. (Des) cortesía, agresividad y violencia verbal en la sociedad actual Sevilla: Universidad Internacional de Andalucía, 2008a. p. 21-58.

FUENTES RODRÍGUEZ, Catalina, ALCAIDE LARA, Esperanza. Descortesía y agresividad. En: FUENTES RODRÍGUEZ, Catalina, ALCAIDE LARA, Esperanza. (Des)cortesía, agresividad y violencia verbal en la sociedad actual Sevilla: Universidad Internacional de Andalucia, 2008b. p. 15-18. 
FUENTES RODRÍGUEZ, Catalina. Salvados por la cortesía estratégica. Revista de Filología, Laguna, n. 32, p. 99-124, enero 2014. Disponible en: http://publica.webs.ull.es/upload/REV\%20 FILOLOGIA/322014/Revista\%20de\%20Filolog\%C3\%ADa\%20 32.pdf.

IMBERT, Gerard. 'Telebasura': de la telerrealidad a la teleficción. El País, 10 enero 2005. Disponible en: http://elpais.com/ diario/2005/01/10/sociedad/1105311611_850215.html. Acceso en: 10 abr. 2019.

LÓPEZ SERENA, Araceli. De la oralidad fingida a la oralidad simuladora de realidad. Reflexiones en torno a la coloquialización del discurso como estrategia mediática. Español actual: Revista de Español Vivo, Sevilha, n. 102, p. 37-75, 2014.

MARTÍNEZ, Valentín Alejandro; JUANATEY-BOGA, Óscar; GONZÁLEZ, Javier Orosa; RODRÍGUEZ CAMPO, Lorena. La teoría de Noelle-Neumann sobre "La espiral del silencio" aplicada a las audiencias de la "telebasura". En: CONGRESO INTERNACIONAL DE ETICA Y DERECHO DE LA INFORMACIÓN, 3., 2004, Valencia. Comunication 21 [...]. Valencia, 2005. p. 435-450. Disponible en: https://dialnet.unirioja. es/servlet/articulo?codigo=2539167. Acceso en: 10 abr. 2019. ORTIZ VISO, Tinúviel; FERNÁNDEZ GARCÍA, Francisco. La agresión verbal como espectáculo: estrategias de descortesía en Sálvame. Oralia, Madrid, v. 17, p. 289-315. 2014

PALOMO, M. (). Telerrealidad: las pantallas son suyas. $E l$ País, 12 Jul. 2014. Disponible en: http://cultura.elpais.com/ cultura/2014/07/11/television/1405095209_922407.html. Acceso en: 10 abr. 2019.

PÉREZ RODRÍGUEZ, M. El discurso televisivo: un lenguaje seductor que cuenta un mundo virtual. Comunicar, Huelva, v. 25, p. 197-202, 2005. Disponible en: http://www.revistacomunicar. com/index.php? contenido $=$ detalles $\&$ numero $=25 \& \mathrm{a}$ 
rticulo=25-2005-027. Acceso en: 10 abr. 2019.

SÁNCHEZ-ESCRIBANO, Israel Vacas. La 'Belenestebanización' de la sociedad. Razón y Palabra, Quito, v. 16, n. 78, p. 1-23, nov./ enero 2012. Disponible en: http://www.razonypalabra.org.mx/ varia/N78/2a\%20parte/30_Vacas_V78.pdf. Acceso en: 10 abr. 2019.

SOPEÑA BALORDI, Amalia; OLIVARES PARDO, M. Amparo. Actos lingüísticos descorteses. En: CASAL, M. L. (ed.). La lingüística francesa en España camino del siglo XXI. Santiago de Compostela: Arrecife, 2000. p. 1025-1035.

SOTO VIDAL, Laura. Prensa rosa: el juego sucio de periodistas y famosos. Estudios sobre el Mensaje Periodístico, Madrid, v. 11, p. 193-209, mayo 2005a. Disponible en: http://revistas.ucm.es/index. php/ESMP/article/view/ESMP0505110193A/12465. Acceso en: 10 abr. 2019.

SOTO VIDAL, Laura. Televisión rosa: Amarillismo y Telebasura. Revista Latinoamericana de Comunicación Chasqui, Quito, n. 90, p. 52-57, jun. 2005b. Disponible en: http://www.redalyc.org/ pdf/160/16009010.pdf. Acceso en: 10 abr. 2019.

'TELEBASURA'. En: DICCIONARIO DE LA REAL ACADEMIA ESPAÑOLA. Madrid: RAE, 2016. Disponible en: http://dle.rae.es/?id=ZLNtc1D. Acceso en: 10 abr. 2019. 